\title{
Politics of a Different Kind: Chinese in Immigration Litigation in the Post White Australia Era ${ }^{1}$
}

\author{
Jia Gao ${ }^{2}$ \\ The University of Melbourne
}

\begin{abstract}
The first mass Chinese immigration to Australia occurred in the 19th century, with approximately 100,000 Chinese arriving between the 1840s and 1901 (Fitzgerald 2007; Ho 2007), during which questions were raised both in relation to the Chinese rights of migration and settlement in Australia, and the validity of the government's actions against the Chinese. The latter question was in fact considered in the colonial courts (Cronin 1993; Lake and Reynolds 2008). Since then, the Chinese in Australia have never shied away from taking various legal actions, although they are normally seen as people who keep to themselves. Australia abandoned its 'White Australia' policy in 1974, and lately Australia has placed more emphasis on skilled and business migration. As a result, many believe that Chinese migrants have come to Australia under its normal skilled, business or family migration programs. This ignores the fact that a high proportion of them have obtained their chance to stay in Australia directly through a series of litigations over their political asylum claims or indirectly through the effects of Court rulings. This paper contributes to the discussion of the Chinese in Australian political life by looking at how the Chinese have fought against adverse executive decisions on their applications for asylum, or more generally against a culture of control that has spread in Australia to prevent unwelcome arrivals (Cronin 1993; Kneebone 2010). It documents key features of their experiences. This is a different type of political activism, characterising the lives of many Australian Chinese, their engagement with the Australian political system, and becoming part of the background of their identity, transnationality, socio-political attitudes and behaviour and many other traits.
\end{abstract}

\section{Introduction}

Chinese migrants have been part of immigration litigation in Australia since the second half of the nineteenth century (Rolls 1992; Fitzgerald 2007). The case of Toy v Musgrove in the late 1880s and 1890s has been considered the leading example in Chinese efforts in litigating for their rights of settlement in Australia (Bennett 2007; Dow 1972). Their efforts to utilise legal channels to fight against exclusion in the first stage of their settlement in Australia were extended into the next period, when Australia became a federation in 1901. The White Australia policy was introduced in the same year through two legislations: the Immigration Restriction Act 1901 and the Pacific Island Labourers Act 1901. In fact, the first legislation contained some loopholes (Palfreeman 1967), resulting in the large number of Court cases filed by Chinese settlers. Since then the Chinese settlers in Australia have never shied away from taking various forms of legal action, some of which have even set precedents in the Australian legal system. In the more recent tide of immigration litigation, the most famous

\footnotetext{
${ }^{1}$ This is a revised version of the paper that the author presented at the 'Chinese in Australian Politics' Colloquium held at University of Technology, Sydney on 8 September 2010, and the author would like to thank colloquium participants for their valuable comments and encouragement.

${ }^{2}$ The author also wishes to acknowledge the research funding support provided by the Faculty of Arts at the University of Melbourne, and the comments of two anonymous referees and the editor on the paper.
} 
Court battle has to be the case of Chan Yee Kin of 1989, which set the boundaries for refugee determinations in Australia (Crock et al. 2006).

However, as a result of theoretical development in the field of international migration studies since the 1980s (Black 1991), scholars of overseas Chinese studies have somehow overlooked the case of Chan Yee Kin, which has simply become a topic of interest for researchers in Australian immigration and refugee law (Crock 1998a; McMillan 2002). Researchers have devoted a great deal of their attention to the issues associated with postmigration experiences and a range of aspects of their lives in Australia, especially to topics that are related to new theoretical explanations in international migration and ethnic studies. There are a small number of studies focusing on pre-migration experiences and a number of factors of the migration process of new Chinese migrants to Australia (Kee 1992; Kee and Skeldon 1994; Coughlan 1996; Viviani 1996; Ho and Coughlan 1997; Coughlan 1998; Harris and Ryan 1998; Sun 2002). An effort has been made to explore how tens of thousands of Chinese students living in Australia campaigned for their right to stay in the country after the June 4 event of 1989 (Gao 2006, 2009). However, it is fairly evident that a large proportion of research publications in the field have focused on a range of settlement-related issues rather than other aspects of the migration process.

The unbalanced research focus on settlement-related issues has blurred our understanding of the totality of migration experiences of the more recent Chinese immigrants. One such neglected area has been the various forms of action that Chinese asylum seekers have taken to confront a strong and persistent 'culture of control' that has dominated the immigration policy-making process and policy outcomes in Australia (Cronin 1993; Jupp 2002; Kneebone 2010). Without taking into account of how the majority of new Chinese immigrants have obtained their right to stay in Australia, researchers have offered less reliable and less systematic explanations for analysing essential issues related to the Chinese immigrant experience, such as their settlement pattern, identity, socio-political attitudes and behaviour and transnationality. This paper focuses on an understudied aspect, the political activism that the Chinese asylum seekers have undertaken in their fight to gain refugee status in the Courts in the post-White Australia era, and outlines the key features of this political action. 


\section{The Tide of Immigration Litigation and the Chan Case}

Australian society had undergone a decade of transformation from the late 1960s to the early 1970s, which was characterised by strong, widespread opposition to the Vietnam War. The Whitlam Labor government was elected in 1972, and the new government decided to withdraw Australian troops from Vietnam while introducing a range of far-reaching changes domestically. One of the most important changes introduced by the new government was the abolition of the White Australia policy. As a result, tens of thousands of non-white migrants from Asia and the Middle East were accepted as immigrants into Australia throughout the second half of the 1970s and the 1980s, including refugees from Vietnam. Although the White Australia policy was officially abandoned, the Migration Act 1958 still guided decisions, giving immigration official discretion over who was admitted into Australia and who should be refused. The discretionary powers and executive decisions on entry and deportation remained unchallenged for most of the 1970s at the administrative level (Cooney 1995; McMillan 2002). As a consequence, a consensus emerged among immigrant advocates and legal professionals as to what role judicial review could play in assessing the legality of immigration decisions.

Two developments of the Australian legal system in the late 1970s drastically changed the legal landscape in Australia, resulting in 'unabated expansion of immigration litigation' in the words of John McMillan, the current, and longest serving, Commonwealth Ombudsman of the country (2002, p. 17). The first of such developments was the establishment of the Federal Court of Australia in 1976, which made new avenues available to any immigrant wishing to dispute an unfavourable administrative decision, and the second was the enactment of the Administrative Decisions (Judicial Review) Act 1977, which included a series of changes sympathetic to immigrants in terms of the chance for judicial review of adverse immigration decisions. The result of these changes was that the state logic of controlling immigration, especially its managerial procedures, started to be disputed in Courts of Law by disappointed asylum seekers or residency applicants. These extensive changes also caused an intense debate in Australia since the early 1980s about its refugee and immigration policies and programs (Betts 1988), making many Australians either very compassionate or unsympathetic to immigrants. It was also in the 1980s that there was a substantial increase in arguments about whether many immigration-related rules were being correctly applied. This is why many Australian legal professionals and immigrant advocates were also increasingly 
aware that the judicial review introduced by the Administrative Decisions (Judicial Review) Act 1977 needed to play a more active role than before in reviewing migration decisions (Douglas 2006).

At the same time, the culture of immigration control has become stronger and more sophisticated than before since the 1980s, shared by both sides of Australian politics (Jupp 2002, p. 63). This culture is deeply rooted in Australian public opinion and politics, dating back to early colonial times. After more than a hundred years, it has developed a number of dimensions, ranging from general cultural constructions of immigrants or asylum-seekers, such as suspicion, and various ideological notions, to partisan political approaches, institutional measures and legal frameworks. Historically, a unique dimension of Australia's culture of control was its focus on the Chinese, and its resurgence in the post-White Australia era is no different from its past. The increasingly large numbers of Chinese over-stayers and onshore asylum seekers since the 1980s have been a direct reason for not only the resurgence of the culture, but also for its long durability. Over the past decades, analysts of the immigration processes inside and outside the government system have constantly assessed who are to be the controllers, who are to be controlled, and how controls are to be exercised (Cronin 1993). Between 1989 and 1992, for example, the Migration Act had been amended 11 times, the Regulations governing immigration programs had seen 58 amendments, and more than six major changes were made to the humanitarian and refugee programs, toughening the control over immigration intake, especially onshore applications for asylum (Gao 2010). In such an unfavourable situation, many Chinese asylum seekers have turned to the Courts to fight against adverse executive decisions on their asylum applications.

Throughout the post-White Australia period, Chinese residency seekers have been the largest numerical group in the litigant population. Although many of them were not successful in their appeals, some have won their cases, providing a legal basis for further Chinese residency claims. It has to be admitted that although Chinese residency seekers have been the largest numerical group in the litigant population, they were not the first group of immigration litigants in the post-White Australia era. This was because Chinese immigrants to Australia in the late 1970s and early 1980s came mostly from the so-called 'Nanyang' countries of Southeast Asia through a range of immigration programs and from Vietnam as part of the boat people exodus of the time. In fact, more than a decade before Australia 
abandoned its White Australia policy in 1974, the Colombo Plan that was launched in 1950 among Commonwealth countries had brought thousands of students with ethnic Chinese backgrounds into Australian universities from various parts of Southeast Asia (Oakman 2004). Many of them stayed in Australia after their studies or migrated back to Australia after working in their sending countries for a short period.

The first Chinese litigant in the late 1970s was a student from Hong Kong, who applied to the Administrative Appeals Tribunal (AAT) in 1977 for review of the decision of the immigration department to deport him from Australia (see Chan and Minister [1977] AATA 19). The AAT reviewed 12 immigration-related cases in 1978, and one of the litigants was clearly identified as being born in New Zealand of Chinese parents (see Gin and Minister [1978] AATA 47). Obviously, the number of immigration-related AAT applications in 1978 was a sign of that not only were the Chinese litigants not the first group of residency seekers to litigate against adverse executive decisions, but they also did not account for a big fraction of litigation cases in the late 1970s. In the first year of the 1980s, the AAT reviewed only two immigration-related cases pursued by ethnic Chinese. The first of these was from a Singaporean family with ethnic Chinese background (see Ang and Minister [1980] AATA 15), while the other was from a person of ethnic Chinese origin, who became frightened of being imprisoned in Indonesia if being forced to return (see Kuswardana and Minister [1980] AATA 63).

In 1986, six immigration-related cases received by the Federal Court came from litigants who could be clearly identified as ethnic Chinese (see Sheng v Minister [1986] FCA 27; Li v Minister [1986] FCA 68; Meggs v Minister [1986] FCA 318 and Soo v Director [1986] FCA 135). Among these six cases, the Federal Court failed to note that two of them were actually from people with Chinese background (see Chua v Minister [1986] FCA 213 and Tang v Minister [1986] FCA 214). As with cases brought to the AAT, these six cases formed only a minority of the total 31 immigration litigation cases in the Federal Court of Australia in 1986, but they indicated the beginning of a new period in Australian immigration history in which more Chinese residency claimants and asylum seekers chose to seek their right to stay in Australia from the Courts. These six Federal Court cases were of particular significance in studying the history of Chinese immigration to Australia, because they included the first application from a Chinese mainlander to the Australian Courts. According to what was 
recorded in Li v Minister (1986) FCA 68, the litigant was from mainland China in 1982 and overstayed his entry permit in 1983. He took his case to the Federal Court in Western Australia to contest the decision of the immigration department to deport him from Australia to China. This first legal action taken by a person from mainland China appeared to have confused legal professionals in Australia, who did not even spell the litigant's name accurately in the court documents.

A similar situation arose in a case before the AAT in 1985 for the reviewing of an executive decision made by the immigration department on the access of the applicant Chan Yee Kin to documents relating to his own asylum application. Although the name of Chan Yee Kin was not spelt in the Chinese official Romanisation system, Chan was in fact from mainland China. His name was spelt incorrectly as ‘Chan Yee Kim’ in at least two AAT documents (see Chan and Department [1985] AATA 119 and Chan and Department [1985] AATA 149).

Chan's application to the AAT was the very first step in his series of legal battles against the immigration department, which went to the High Court in 1989, and became the landmark High Court case of Chan Yee Kin. Chan's story, as recorded in the court documents appeared to contain inconsistencies. He was born in 1951 in China. He appeared to grow up in a city in Southern China, but it is difficult to explain how he became a Red Guard if his father was a member of the Kuomintang (Nationalist Party), who escaped from China in 1950, but also was able to return to China from time to time. All these seem to suggest that he might grow up in a big city where his 'anti-revolutionary' family background was insignificant.

Australian immigration officials and judges also did not ask how he was able to become a Red Guard if he left school in 1965, an obvious contradiction to known facts that the Maoist Cultural Revolution started in mid-1966. No question was asked by immigration officials and judges as to why he was detained by police in 1968 and listed in his local area as a person opposed to the government. According to courts records, Chan Yee Kin escaped from China in 1974 to Macau, and his father who was living in Hong Kong helped him obtain a temporary identity certificate in Macau. Chan then went to Hong Kong and stayed there unlawfully for years. Having been unsuccessful in seeking legal resident status in Hong Kong, he was detained and then deported to Macau, but he soon returned to Hong Kong illegally to seek an opportunity to board a ship to Australia. Chan entered Australia illegally 
in August 1980 according to a High Court document, or in November 1980 according to a Federal Court file. From April 1982 to February 1983, he was detained in Melbourne.

In November 1982, Chan started his extended legal battle to seek political asylum in Australia. Case officers from the immigration department first interviewed him in December 1982, and the Determination of Refugee Status Committee (DORS) also considered his case in July 1983, but decided not to grant him refugee status. The Chan case then went through a series of reviews. In November 1983, an internal review was conducted by the immigration department, which concluded that Chan was not a refugee. His case was then reconsidered for a judicial review during 1985. In October of that year, the first review accepted the decision made by the immigration department. Chan decided to seek another internal review by the immigration department. In June 1986, Chan was once again interviewed by a case officer designated by the immigration department, through which he had his refugee application re-examined by the DORS in August 1986. The DORS once again concluded that Chan was not a refugee, because his case contained no evidence proving a 'well-founded' fear of persecution, a key element of the refugee definition. At the same time while Chan was coping with the above reviews, he formed a de facto relationship with a temporary entry permit holder from Malaysia in 1984. The birth of their first child in April 1985 made his case more complicated than at the beginning. Since April 1985, Chan and his de facto partner had not only applied for Australian residency individually, but their first child had also become a third party to each of their applications. In late 1986, one of their applications went to the Federal Court, where he received a favourable court ruling from Mr Keely, a Federal Court judge in Chan v Minister (1987) 14 ALD 172, in which Mr Keely ruled that Chan was entitled to be granted refugee status. The immigration department appealed soon after against the ruling to a Full Court of the Federal Court, which reversed Keely’s judgment in July 1988 in Minister v Chan (1988) ALD 751.

Having been denied refugee status five times within a span of five years, Chan's only choice after the Full Federal Court was to take his case to the highest court in Australia. In 1988, when Chan was preparing his appeal to the High Court of Australia, there were not many onshore asylum seekers. It was also in the late 1980s that the collapse of the Eastern Bloc resulted in sweeping changes in international politics, one effect of which was that asylumseeking became much easier for people from certain countries including China. Chan was 
fortunate in having dragged his case out for so many years and from its continuing on into 1989, when the Tiananmen incident occurred in China in June 1989. His application to the High Court was heard before the Tiananmen incident, but the ruling was delivered after, in September 1989. The High Court not only ruled that the decision made by the immigration department on Chan's case was unreasonable, but it also considered the definition of 'refugee'(Crock 1998a, 2004; Aronson and Dyer 2000), and this had a major impact on the Australian government's decision on the 45,000 Chinese nationals who were also seeking to stay in 1989.

The High Court's ruling on the Chan case was a big blow to the culture of immigration control. The decision had changed the interpretation of the refugee definition, a key point of which is that the definition would be satisfied if the fear of persecution has a reasonable basis in that there is a 'real chance' that the person could be in danger of persecution upon return to their home country (Crock 1998b). The High Court decision on the Chan case also interpreted the meaning of the persecution, and expanded it to include any harm that could be considered offensive by ordinary people in Australia. More controversially, the High Court also rejected the argument that objective assessment of the 'well-founded fear' requires proof that the applicant would, in fact, be persecuted if returned to their country of origin.

The High Court decision on the Chan case was perceived as a piece of good news by the Chinese nationals who were seeking asylum in Australia, and their reading of the decision was that they must demonstrate their subjective fear of persecution upon return to China first, before substantiating it with evidence. It was through the High Court decision that more Chinese nationals living in Australia realised the extent to which Australian elites understood Chinese politics and the political behavior of Chinese people. To test whether the principles established by the High Court in the Chan case were applicable to the so-called Chinese student issue, five Chinese students studying at the Australian National University decided to take the immigration department to Court after a lengthy consultation process with refugee activists and their lawyers.

According to Wei v Minister [1991] FCA 207; 29 FCR 455), these five students came to Australia before June 1989 in order to pursue their postgraduate studies. They all applied for residency on humanitarian grounds, while four of them also submitted applications for 
refugee status. But, they did not ask the Court to reassess the merit of their cases, and instead, they sought judicial review with regard to the failure of the immigration department to make a decision on their humanitarian applications. This was once considered to be a very strategic action to seek judicial review of the immigration decision-making process first before taking any other legal action. The Federal Court in the Australian Capital Territory (ACT) ruled against the immigration department in May 1991 on the basis of 'bureaucratic delays' in making decisions on the students' applications for residency on humanitarian grounds. According to Marion Le, the lawyer who had assisted these five students, this particular Federal Court decision resulted in more than 2,000 Chinese nationals of the 4,300 or so humanitarian applicants registered on and before 31 March 1990 being granted residency, which opened the door to the processing of some 20,000 others (DIEA 1994, p. 6; Le 2001).

Because of the combined effects of the above two court decisions, the Hawke Labor government had no option but to start dealing with the protection demand from 45,000 or so Chinese nationals who were living in Australia. A special four-year temporary protection visa was legislated and offered to all those 45,000 Chinese nationals. This large group of onshore residency seekers were finally allowed to stay permanently as a result of the Keating Labor government’s ‘1 November 1993 decisions’ and the Howard government’s ‘13 June 1997 decisions’ (Birrell 1994; DIMA 1997). The then Labor minister for immigration, Mr Gerry Hand, once estimated that if the spouses and children of these 45,000 Chinese nationals were included, plus the effects of chain migration, 'the original 17,000 Chinese might increase to 300,000 by the turn of the century' (Jose 1995, p. 58).

\section{The Intensified Politics of Residency}

The ' 1 November 1993 decisions' resolved the problem of the so-called Tiananmen group of Chinese residency seekers, but generated significant pressure on many other Chinese nationals who arrived in Australia later and missed out the opportunity offered by the Keating government. That is, the ' 1 November 1993 decisions' had eventually intensified political efforts of many Chinese political asylum claimants to seek residency in Australia. Seeking asylum in a foreign country is a kind of politics which requires a strategic approach and skills. To casual observers, the chain migration effects from the granting of residency to 45.000 students attracted many later arrivals from China, while student visa holders have become one of the main sources of on-shore immigration. In addition, more have also come 
under the skilled and business permit programs. What has been ignored is the fact that, among the Chinese who have obtained Australian residency since 1993 when the student issue of 1989 was resolved, there is also a large number who have been allowed to stay because of many court battles over their asylum claims.

The Chinese nationals’ efforts to harness resources to seek their chance to stay in Australia in the post-1993 years were once described as 'Baxian guohai' (the Eight Immortals crossing the sea), a well-known Taoist story about how the Eight Immortals were crossing the sea because of their special skills. Of course, as the legend goes, this particular saying has its second half, ending with 'gexian qineng' (each showing his or her special prowess). One peculiar 'prowess' that new Chinese residency claimants or asylum seekers have utilised after 1993 and 1994 is to litigate against unfavourable executive decisions on their asylum applications on every possible front, ranging from immigration-related procedural issues to more complicated issues based upon socio-political and ideological differences between the West and China. The latter includes political opinions, China's controversial one-child policy, ethnic conflicts, same-sex relationships, religious activities including house or underground churches, the Falun Gong, and even corruption-related claims. Obviously, many of the grounds on which asylum claims were based are closely linked to the refugee definition, and are political in essence, forming a new feature in their campaign to stay in Australia.

Earlier cases of litigation pursued by the post-Tiananmen group of onshore Chinese asylum seekers took place in 1993 and 1994, when the immigration department was solving the Chinese student issue. Those who missed out on the chance provided by the ' 1 November 1993 decisions' began taking legal action to seek their right to stay and their actions were often taken without any clear strategic thinking or focus. The attention of many court cases focused narrowly on procedural issues, as in Zhang v Minister (1993) 118 ALR 165, and Li v Minister (1994) 35 ALD 557. Attention was so focused on procedural issues that the second High Court ruling on immigration litigation involving Chinese asylum seekers in the postWhite period was made in Minister $v$ Wu (1996) HCA 6. In this case the High Court commented on the approach to be adopted by lower Courts when scrutinising a statement of reasons. 
In the aftermath of the so-called Chinese student issue, which remains the largest onshore migration intake in Australian history (Gao 2009), and also in response to a number of boat arrivals in 1992 (Khoo et al. 2008), the level of public acceptance of immigrants and refugees appeared to have waned in Australia in the early 1990s (Jones 2003). Evidence for this is to be found in the introduction of mandatory detention laws in 1992, a bipartisan support to the culture of immigration control. Another increase in boat arrivals and subsequent asylum claims in 1993 and 1994 not only resulted in more strict policies to deal with irregular migration (Schloenhardt 2000), but also in a low public acceptance of asylum seekers. As a result, more Chinese asylum seekers not only had to seek their chance to stay in Australia from the Courts, but also to politicise their claims. Also because court battles were becoming difficult to win, various legal actions taken by Chinese litigants from the mid-1990s appeared more strategic. The first strategic theme in the intensified legal actions was the utilisation of China's controversial one-child policy as grounds to apply for political asylum (Crock 1995). Such an effort was first reported in Minister v Respondents (1994) ALR 383, in which a young Chinese couple won their application in the Federal Court. This case was a turning point in the asylum-seeking strategies of Chinese litigants. After this case, China's fertility control policy has been used in seven High Court challenges, more than 200 Federal Court applications, about 40 AAT appeals, over 100 Immigration Review Tribunal applications before 1999. Since 1999, there have been approximately 430 Migration Review Tribunal applications, and about 1,200 Refugee Review Tribunal (RRT) cases.

The successful utilisation of China's fertility control policy by Chinese nationals in seeking asylum in Australia caused public outcry (Poynder 1995). Urgent political actions were taken by Australian policy-makers to revise immigration laws and limit refugee claims related to the fertility control policy (Betts 1997). While more legal elites were under the influence of the resurgent culture of control, some one-child-policy-related applications, such as Guo v Minister (1995) ALD 38, were rejected in 1995. In the same year, the abovementioned Minister v Respondents (1994) ALR 383 was also overturned by the Full Federal Court in Minister v A (1995) ALR 48, in which, the Court held in favour of the immigration department, finding that litigants who feared forced sterilisation did not constitute a 'particular social group' for refugee status. This particular decision was upheld by the High Court in Av Minister (1997) HCA 4, which led the emergence of a new feature in their 
political asylum claims and court actions, characterised by an emphasis on a membership of a 'particular social group'.

The resurgent culture of control over immigration issues resulted in a series of changes to the strategy of Chinese residency claimants. The first strategic change was the inclusion of the 'black children', or unregistered children who were born outside the birth-control plan (Sackville 2004), into new asylum applications, which proved to be useful in several cases, such as in Chen v Minister, BC9802287. 'Black children' were accepted as a type of social group as indicated in the refugee definition (Marsic 2000), and this was subsequently confirmed by the High Court in Chen v Minister (2000) HCA 19 and S v Minister (2004) HCA 25. Since then, the reasons Chinese asylum seekers utilised for seeking refugee status were seen to have been adjusted, paying more attention to other crucial, or highly politicised, elements of the refugee definition than 'a particular social group' and 'political opinion', the last two components of the definition (Black 1991). More cases were based on race and religion, the first two elements of the refugee definition, a closer fit with the socio-political and ideological differences between China and the West than had been used in earlier cases.

These strategic changes resulted in a large number of new claims based on ethnic conflict issues in China, such as in Fu v Minister (1996) FCA 1416, Ming v Minister (1998) FCA 534, Li v Minister (1999) FCA 779, and underground religious activities or house churches in China as in Chen v Minister (1996) FCA 1398, Li v Minister (1997) FCA 289, Chen v Minister (1997) FCA 511, and Lin v Minister (1999) FCA 573. The notion of 'particular social group' was still in use, but was found to have included homosexuals after several cases were won from 1994 to 1996 such as in Guo v Minister (1998) FCA 1592, (Walker 1996). The concept was also extended to the people who were the targets of China's anti-corruption campaigns, such as in Cai v Minister (1997) FCA 1219, Xu v Minister (1997) FCA 1173, and Zheng v Minister (2000) FCA 670.

Aside from the religion-related cases, which will be analysed next because their links to the latterly emerged Falun Gong issue, ethnic issues, homosexuals, and people targeted by China's anti-corruption campaigns have formed the basis of many claims since the second half of the 1990s, and each ground for claim has been used many times. In 1993, the RRT reviewed only two ethnicity-related applications from ethnic Chinese litigants, but the 
number of cases increased to 76 in 1994, 91 in 1995155 in 1996 and 228 in 1998. At the same time, more Chinese litigants also tried to base their asylum claims on multiple grounds. As a key feature of their litigation, this tactic was used in one of the earlier court cases such as $C v$ Minister (1995) FCA 1164 that was based on three grounds: China's fertility control policy, and forced sterilisation and its effect on Christian beliefs. The same approach was also used by the litigant in the aforementioned Lin v Minister (1999) FCA 573, which included religious beliefs, the fertility control policy and litigant's involvement in the democratic movement of 1989 and the anti-corruption campaign in his home region.

As mentioned, there has been an ongoing effort by Chinese asylum seekers to base their claims on religion-related grounds since the mid 1990s, which has intensified since the Falun Gong was banned in China in 1999 (Perry 2001). The number of such claims has been so large that Chinese litigants appear to believe that religious activities are the best ground for seeking asylum. This type of claim fits well into the political-ideological gap between China and the West, and it therefore appears easy to convince case officers or tribunal members. Religion-related claims were first made when China's fertility control policy was no longer helpful in seeking asylum in Australia. Yet, a large number of earlier religion-based applications seemed effortless, simply declaring that the applicant had a fear of being persecuted in China for religious beliefs. According to Federal Court records, Christian beliefs were first used in C v Minister (1995) FCA 1164 and Chen v Minister (1996) FCA 1398, Catholic beliefs were first mentioned in Chen v Minister (1997) FCA 511, while the first case concerning Protestant beliefs appeared later, in 2000 in Wang v Minister (2000) FCA 511. As recorded in Li v Minister (1997) FCA 289, one Chinese litigant even made a claim based on both Christian and Buddhist practices.

The online databases of AustLII (the Australian Legal Information Institute) have recorded thousands of religion-based cases being pursued by Chinese asylum seekers and reviewed by the RRT, with only less than 10 percent of that number going to the Federal Court for review. As of 10 July 2010, the RRT online database records 1,481 Chinese litigation cases based on Catholicism-related claims, but the Federal Court database recorded only 96 mentions of Catholicism. Among those 1,481 RRT review cases, there were three in 1993, 119 in 1994, 169 in 1995, 192 in 1996, 149 in 1997, 188 in 1998 and 104 in 1999. Also as of 10 July 2010, the RRT database records 2,392 Chinese litigation cases mentioning the broader concept of 
Christianity. Among these, 11 cases were reviewed in 1993, 183 in 1994, 226 in 1995, 243 in 1996, 279 in 1997, 334 in 1998 and 160 in 1999. The same database has 1,231 cases pursued by the Chinese referring to both Christianity and Catholicism, among there were only three review cases in 1994, 109 in 1994, 132 in 1995, 144 in 1996, 115 in 1997, 142 in 1998 and 87 in 1999. There are also 1,165 Chinese litigation cases mentioning Protestant beliefs, which was first made in V93/00002 (1993) RRTA 29 in 1993, but only 30 Federal Court cases and 36 Federal Magistrates Court cases were based on the same ground. Muslim or Islam was mentioned in 1,529 RRT cases involving Chinese litigants while 51 such cases were reviewed by the Federal Court. Among 1,529 RRT Muslim- or Islam-related cases, there were only two cases in 1993, 35 in 1994, 137 in 1995, 164 in 1996, 234 in 1997, 205 in 1998 and 100 in 1999. These types of case have been so common that the High Court of Australia was once again asked to rule whether certain procedures are lawful in Minister $v$ Wang (2003) HCA 11, and Minister v SZKTI (2009) HCA 30.

As indicated by the above figures, the year 1999 saw a decline in the number of review cases across all conventional religion-based application categories. However, 1999 also saw a significant increase in the number of Falun Gong-based claims, which has maintained a high level of utilisation of litigation by Chinese asylum seekers in seeking residency in Australia throughout the decade of the 2000s. A detailed review of court documents show that a couple of years before 1999, when the Falun Gong became a new topic of international politics, some refugee tribunal members and judges in Australia seemed to have realised that certain religious practices are allowed in China. Some Chinese official publications that were normally regarded by many Westerners as Chinese propaganda materials were cited in more court documents to prove that some religious practices are not punishable in China. The banning of the Falun Gong in 1999 by the Chinese government (Perry 2001) created a new ground on which asylum could be sought in some Western countries including Australia.

It was also in 1999 that the Federal Magistrates Court was established in order to provide a simple alternative to litigation in the Federal Court. Since then, the Federal Magistrates Court has received 1,140 or so Falun Gong-related cases in the first ten years of its history, while 1,016 Falun Gong-based review cases went to the RRT and 539 of them were reviewed by the Federal Court. The RRT received and reviewed four Falun Gong-based asylum applications in 1999, and the number had then increased to 46 in 2000, 90 in 2001, 84 in 
2002, 118 in 2003, and 75 in 2004. Since 2004, Falun Gong-related cases have been reviewed by the Federal Magistrates Court, which started with 45 in 2004 and then increased to 161 in 2005, 207 in 2006, 357 in 2007, 245 in 2008 and 121 in 2009. All these claims have further demonstrated that the asylum-seeking process, asylum-related litigation in particular, is a type of politics that many Chinese asylum seekers have actively engaged in the past two or so decades. The politics of this kind has added a number of thousand new cases into the already large group of Chinese litigants seeking asylum in Australia.

\section{Conclusion}

This has been an examination of how thousands of Chinese asylum seekers have taken legal actions in the Australian Courts as part of their efforts to stay in the country. In the postWhite Australia period, Chinese migrants were in fact not the first group of immigration litigants, nor were there many of them seeking their right to stay in Australia from the Courts in the earlier years of the period. Since the landmark High Court decision on the Chan case, however, thousands of Chinese have brought cases in the Australian Courts in their efforts to seek residency in the country. According to the 1986 Census, Australia had only 200,000 or so people claiming primary and secondary Chinese ancestry (Kee 1992). After the ' 1 November 1993 decisions', the 1996 Census recorded that speakers of 'the Chinese varieties' totalled 343,523 people (Clyne and Kipp 1999), roughly the same number as the then Labor minister for immigration, Mr Gerry Hand, had estimated if each of 45,000 Chinese nationals brought in one spouse and one child. According to the 2001 Census, the number of Chinese speakers had increased to 401,357, with 555,560 claiming Chinese ancestry (Chan 2005), proving that Gerry Hand's prediction of having 300,000 Chinese by the turn of the century was correct (Jose 1995, p. 58). In 2006, the number of Australian residents claiming to be of Chinese ancestry rose to 669,900 (ABS 2007), with more than 500,000 Chinese language speakers.

Based on these figures, it is possible to speculate that although Australia has placed more emphasis on various skilled and business migration programs, thousands of Chinese did not migrate through what can be seen as normal immigration programs, but through the refugee programs, especially as a result of many legal actions over their asylum claims. Their legal actions also reveal that many Chinese immigrants are not only capable of identifying how the 'culture of control' was exercised, but were able to turn it to their advantage. This is the 
poorly-recognised experience of thousands of Chinese immigrants in Australia in its postWhite Australia era. These attempts to escape or to exploit the culture of control has characterised their lives in Australia, and become part of the background of their identity, socio-political attitudes and behaviour.

\section{References}

ABS (Australian Bureau of Statistics) 2007, 2006 Census of Population and Housing: Media Releases and Fact Sheets 2006. Available at http://www.abs.gov.au/ausstats/abs@.nsf/mf/2914.0.55.002/ (Accessed in July 2010).

Aronson, M. \& Dyer, B. 2000, Judicial Review of Administrative Action, LBC Information Services, Sydney, Australia.

Bennett, J.M. 2007, George Higinbotham: Third Chief Justice of Victoria 1886-1892, Federation Press, Sydney.

Betts, K. 1988, Ideology and Immigration: Australia 1976 to 1987, Melbourne University Press, Melbourne.

Betts, K. 1997, 'Judicial Activism, Immigration and the One-Child Case', People and Place, vol. 5, no. 3, pp. 19-28.

Birrell, B. 1994, 'The Outcome of the 1 November 1993 Decisions', People and Place, vol. 2, no. 3, pp. 39-46.

Black, R. 1991, 'Refugees and Displaced Persons: Geographical Perspectives and Research Directions', Progress in Human Geography, vol. 15, no. 3, pp. 281-298.

Chan, H. 2005, 'Chinese in Australia' in Ember, M. et al. (eds), Encyclopedia of Diasporas: Immigrant and Refugee Cultures around the World, Volume II, Springer, New York, pp. 634-645.

Cooney, S. 1995, The Transformation of Migration Law, Australian Government Publishing Service, Canberra.

Coughlan, J.E. 1996, 'The Transformation in the Characteristics of Chinese Migration to Australia 1982-1993’, Asian Profile, vol. 24, no. 2, pp. 99-130.

Coughlan, J.E. 1998, 'The Changing Characteristics of Chinese Migrants to Australia during the 1980s and Early 1990s', In Sinn, E. (ed), The Last Half Century of Chinese Overseas, Hong Kong University Press, Hong Kong, pp. 299-345.

Crock, M. 1995, 'The Peril of the Boat People: Assessing Australia's Responses to the Phenomenon of Border Asylum-Seekers', In Selby, H. (ed), Tomorrow's Law, The Federation Press, Sydney, pp. 28-48.

Crock, M. 1998a, Immigration and Refugee Law in Australia, The Federation Press, Sydney.

Crock, M. 1998b, 'Apart from Us or a Part of Us: Immigrants’ Rights, Public Opinion and the Rule of Law', International Journal of Refugee Law, vol. 10, no. 1\&2, pp. 49-76.

Crock, M. 2004, 'Judging Refugees: The Clash of Power and Institutions in the Development of Australian Refugee Law', Sydney Law Review, vol. 26, pp. 51-73.

Crock, M., Saul, B. \& Dastyari, A. 2006, Future Seekers II: Refugee and Irregular Migration in Australia, The Federation Press, Sydney.

Cronin, K. 1993, 'A Culture of Control: An Overview of Immigration Policy-Making', In Jupp, J. \& Kabala, M. (eds), The Politics of Australian Immigration, Australian Government Publishing Service, Canberra.

Clyne, M. \& Kipp, S. 1999, Pluricentric Languages in an Immigrant Context: Spanish, Arabic and Chinese, Mouton de Gruyter, Berlin. 
DIEA (Department of Immigration and Ethnic Affairs). 1994, Annual Report 1993-94, Australian Government Publishing Service, Canberra.

DIMA (Department of Immigration and Multicultural Affairs). 1997, Fact Sheet 35: The 13 June 1997 Visa Decisions, Australian Government Publishing Service, Canberra.

Douglas, R. 2006, Douglas and Jones's Administrative Law, Fifth Edition, The Federation Press, Sydney.

Dow, G.M. 1972, 'Higinbotham, George (1826 - 1892)', In Australian Dictionary of Biography, Melbourne University Press, Carlton, pp. 391-397.

Fitzgerald, J. 2007, Big White Lie: Chinese Australians in White Australia, University of New South Wales Press, Sydney.

Gao, J. 2006, 'Organized International Asylum Seeker Networks: Formation and Utilization by the Chinese Students', International Migration Review, vol. 40, no. 2, pp. 294-317.

Gao, J. 2009, 'Lobbying to Stay: The Chinese Students' Campaign to Stay in Australia', International Migration, vol. 47, no. 2, pp. 127-154.

Gao, J. 2010, 'Negotiating State Logic: How Chinese Students Obtained Residence in Australia’, Omnes: The Journal of Migration \& Society, vol. 1, no. 1, pp. 35-66.

Harris, K. L. \& Ryan, J. 1998, 'Chinese Immigration to Australia and South Africa: A Comparative Analysis of Legislative Control', In Sinn, E. (ed), The Last Half Century of Chinese Overseas, Hong Kong University Press, Hong Kong, pp. 373-389.

Ho, C.H. \& Coughlan, J.E. 1997, 'The Chinese in Australia: Immigrants from the People's Republic of China, Malaysia, Singapore, Taiwan, Hong Kong and Macau’, In Coughlan, J. \& McNamara, D. (eds.), Asians in Australia: Patterns of Migration and Settlement, Macmillan Education Australia, Melbourne, pp. 120-70.

HREOC (The Human Rights and Equal Opportunity Commission) 1998, Those who've Come across the Seas: Detention of Unauthorised Arrivals. Australian Government Publishing Service, Canberra.

Jones, G. 2003, 'White Australia, National Identity and Population Change', In Jayasuriya, L. et al. (eds), Legacies of White Australia: Race, Culture and Nation, University of Western Australia Press, Perth, pp. 110-128.

Jose, N. 1995, Chinese Whispers: Cultural Essays, Wakefield Press, Adelaide.

Jupp, J. 2002, From White Australia to Woomera: The Story of Australian Immigration, Cambridge University Press, Melbourne.

Kee, P.K. 1992, 'The Chinese in Australia: A Brief Historical Overview and Contemporary Assessment', In Chinese Association of Victoria: 1982-1992 the First Ten Years, The Chinese Association of Victoria Inc., Melbourne.

Kee, P.K. \& Skeldon, R. 2004, 'The Migration and Settlement of Hong Kong Chinese in Australia', In Skeldon, R. (ed), Reluctant Exiles?, M.E. Sharpe, New York.

Kneebone, S. 2010, 'Controlling Migration by Sea: The Australian Case', In Ryan, B. \& Mitsilegas, V. (eds.), Extraterritorial Immigration Control: Legal Challenges, Martinus Nijhoff Publishers, Leiden, pp. 347-374.

Lake, M. \& Reynolds, H. 2008, Drawing the Global Colour Line: White Men's Countries and the International Challenge of Racial Equality, Cambridge University Press, London.

Le, M. 1993, 'Reality: The Release of the Isabella Refugees', In Crock, M. (ed), Protection or Punishment: The Detention of Asylum Seekers in Australia, The Federation Press, Sydney, pp. 151-162.

Le, M. 2001, 'Migrants, Refugees and Multiculturalism’, Available at http://www.abc.net.au/rn/deakin/stories/s295948.htm (Accessed in July 2010).

Marsic, S. 2000, 'Do Chinese "Black Children” Constitute a "Social Group” for the Purposes of the Refugee Convention?’, Alternative Law Journal, vol. 25, no. 3, p. 141. 
McMillan, J. 2002, 'Judicial Restraint and Activism in Administrative Law', Federal Law Review, vol. 30, no. 2, pp. 335-371.

Oakman, D. 2004, Facing Asia: A History of the Colombo Plan, Pandanus Books, Canberra.

Orleans, L.A. 1988, Chinese Students in America: Policies, Issues, and Numbers, National Academy Press, Washington.

Palfreeman, A.C. 1967, The Administration of the White Australia Policy, Melbourne University Press, Melbourne.

Perry, E. 2001, 'Challenging the Mandate of Heaven: Popular Protest in Modern China', Critical Asian Studies, vol. 33, no. 2, pp. 163-180.

Khoo, S. E., Ho, E. and Voigt-Graf, C. 2008, 'Gendered Migration in Oceania: Trends, Policies and Outcomes', Piper. N. (ed.), New Perspectives on Gender and Migration: Livelihood, Rights and Entitlements. Routledge, London, pp. 103-138.

Poynder, N. 1995, 'Recent Implementation of the Refugee Convention in Australia and the Law of Accommodation to International Human Rights Treaties', Australian Journal of Human Rights, vol. 2, no. 1, pp. 75-90.

Rolls, E. C. 1992, Sojourners: The Epic Story of China's Centuries-old Relationship with Australia, University of Queensland Press, Brisbane.

Sackville, R. 2004, 'Refugee Law: The Shifting Balance', Sydney Law Review, vol. 26, no. 1, pp. 37-50.

Schloenhardt, A. 2000, 'Australia and the Boat-People: 25 Years of Unauthorised Arrivals', University of New South Wales Law Journal, vol 23, no. 3, pp. 33-55.

Sun, W.N. 2002, Leaving China: Media, Migration, and Transnational Imagination, Rowman \& Littlefield, Lanham.

Viviani, N. 1996, The Indo-Chinese in Australia 1975-1995: From Burnt Boats to Barbecues, Oxford University Press, Melbourne.

Walker, K. 1996, 'The Importance of Being Out: Sexuality and Refugee Status', Sydney Law Review, vol. 18, no. 4, pp. 568-597. 